Research Paper

\title{
Alternative sanitization methods for minimally processed lettuce in comparison to sodium hypochlorite
}

\author{
Mara Lígia Biazotto Bachelli, Rívia Darla Álvares Amaral, Benedito Carlos Benedetti \\ Laboratório de Tecnologia Pós-colheita, Faculdade de Engenharia Agrícola, \\ Universidade Estadual de Campinas, Campinas, SP, Brazil.
}

Submitted: April 20, 2010; Approved: November 13, 2012.

\begin{abstract}
Lettuce is a leafy vegetable widely used in industry for minimally processed products, in which the step of sanitization is the crucial moment for ensuring a safe food for consumption. Chlorinated compounds, mainly sodium hypochlorite, are the most used in Brazil, but the formation of trihalomethanes from this sanitizer is a drawback. Then, the search for alternative methods to sodium hypochlorite has been emerging as a matter of great interest. The suitability of chlorine dioxide (60 $\mathrm{mg} \mathrm{L}^{-1} / 10 \mathrm{~min}$ ), peracetic acid (100 $\left.\mathrm{mg} \mathrm{L}^{-1} / 15 \mathrm{~min}\right)$ and ozonated water $\left(1.2 \mathrm{mg} \mathrm{L}^{-1} / 1 \mathrm{~min}\right)$ as alternative sanitizers to sodium hypochlorite $\left(150 \mathrm{mg} \mathrm{L}^{-1}\right.$ free chlorine $\left./ 15 \mathrm{~min}\right)$ were evaluated. Minimally processed lettuce washed with tap water for $1 \mathrm{~min}$ was used as a control. Microbiological analyses were performed in triplicate, before and after sanitization, and at 3, 6, 9 and 12 days of storage at $2 \pm 1{ }^{\circ} \mathrm{C}$ with the product packaged on LDPE bags of $60 \mu \mathrm{m}$. It was evaluated total coliforms, Escherichia coli, Salmonella spp., psicrotrophic and mesophilic bacteria, yeasts and molds. All samples of minimally processed lettuce showed absence of E. coli and Salmonella spp. The treatments of chlorine dioxide, peracetic acid and ozonated water promoted reduction of 2.5, 1.1 and 0.7 log cycle, respectively, on count of microbial load of minimally processed product and can be used as substitutes for sodium hypochlorite. These alternative compounds promoted a shelf-life of six days to minimally processed lettuce, while the shelf-life with sodium hypochlorite was 12 days.
\end{abstract}

Key words: food safety, chlorine dioxide, peracetic acid, ozone, minimal processing.

\section{Introduction}

The market for minimally processed products has increased significantly in recent years and their popularity come mainly from the facility of preparation, which is recently more required because the products have already been washed, cut and cleaned, and also contributes to decrease of generated waste, besides the full use of the purchased product (Berbari et al., 2001). Concern about microbiological risks becomes pronounced, since, in most cases, the minimally processed products are consumed raw on salads and the human manipulation in some steps of the minimal processing operations increase the risk of contamination by spoilage or pathogenic microorganisms.

Various studies showed the contamination of raw products consumed throughout the world, stressing the need for clean products and food establishments avoiding outbreaks of food poisoning (Tancredi et al., 2005). Recently, between May and July of 2011 in Germany, the consumption of sprouts was identified as the most likely vehicle of an outbreak caused by Shiga-toxin producing Escherichia coli. It was reported a total of 3816 cases, including 54 deaths (Frank et al., 2011).

Sanitization with chlorine products is widely recommended to delay or eliminate microbiological growth in minimally processed vegetables. For economic reasons, the sodium hypochlorite is the most commonly used, although the formation of trihalomethanes, which are carcinogenic compounds due the use of this sanitizer, is a drawback (Ölmez and Kretzschamr, 2009). There are some researches about by-products formation in drinking water disinfection (Richardson et al., 2000, Hua and Reckhow, 
2007), but little information has been published regarding the identification of these toxic compounds during disinfection processes of fruits and vegetables (López-Gálvez et al., 2010). Klaiber et al. (2005) studied the application of cold and warm tap water with and without chlorination (200 $\left.\mathrm{mg} \mathrm{L}^{-1}\right)$, respectively, in the washing of uncut peeled carrots and concluded that the by-product formation due to chlorination was negligible. Some epidemiological researches about the concentration of trihalomethanes with morbidity and mortality from cancer showed positive associations in some cases of carcinomas (Berbari et al., 2001, Bari et al., 2003).

Then, it has been emerging the interest for alternatives of disinfection that can replace chlorine, providing other benefits, not only economical, but also on the aspect of food safety. In some countries the use of sodium hypochlorite is restricted. In Germany, residual chlorine or its reaction products must be absent in minimally processed vegetables at the consumer level not causing adversely effects on odor and flavor and without danger to the consumer health. In France, his use is not actually authorized but only tolerated for disinfection of minimally processed products and the subsequent rising with potable water is obligatory. The same process should be done in United States, which allows the use of this chemical product but only with subsequent washing to remove product excess (Baur et al., 2004). The trend is that this prohibition will happens in other places, so it is necessary some alternatives to minimize or replace this sanitizer.

The Food and Drug Administration of the United States, in its regulation 21 CFR $\S 173,315$, approved the use, in addition to sodium hypochlorite, of the chlorine dioxide, hydrogen peroxide, peracetic acid and ozone as sanitizers for fresh and minimally processed fruits and vegetables (FDA, 2002, Rico et al., 2007). Chlorine dioxide is a chemical agent that forms low concentrations of chloramines and trihalomethanes (Kim et al., 1999). Peracetic acid degrades rapidly into biodegradable and harmless substances such as acetic acid and active oxygen, which offer no toxicity risk and antimicrobial resistance (Costa, 2007). Ozone is a powerful oxidizing and sterilizing agent used in small concentrations and short contact time and has a great advantage of not being a source of pollution, since its product of degradation is oxygen (Prestes, 2007).

Thus, this study aimed to evaluate the effect of chlorine dioxide, peracetic acid and ozonated water as alternatives to sodium hypochlorite in the sanitization of minimally processed lettuce.

\section{Material and Methods}

\section{Raw material}

Lettuce (Lactuca sativa $\mathrm{L}$.) was acquired from a producer in the rural area of Campinas, SP. The product showing a full stage of horticultural maturity was manually harvested, in the early hours of the day, and transported to the Postharvest Technology Laboratory of the Faculty of Agricultural Engineering of the University of Campinas, where the processing was performed. Before processing the raw material was kept under refrigeration at temperature of $12 \pm 2{ }^{\circ} \mathrm{C}$, for a maximum of $4 \mathrm{~h}$.

\section{Processing}

The following operations were used in the lettuce minimal processing (Darezzo, 2004, Chitarra and Chitarra, 2007). After reception, a selection was carried out to remove the product with mechanical injury and rot, followed by the toilet operation in which the external and dirty leaves were withdrawn, besides the lettuce heart. After toilet, the sample 1 (before processing, BP) was removed and the lettuce was pre-rinsed to remove dirt and crop residues, that was carried out in tap water, at ambient temperature, and separation of each leaf with a previously cleaned and sharp knife. Then, the product was transferred to the clean area for the cutting process and the leaves were randomly cut on longitudinal direction. After that, the sanitization was realized with the following treatments: T1 - sodium hypochlorite at concentration of $150 \mathrm{mg} \mathrm{L}^{-1}$ and immersion time of $15 \mathrm{~min}$. The $\mathrm{pH}$ of solution was monitored and kept below 6.8; $\mathrm{T} 2$ - chlorine dioxide at $60 \mathrm{mg} \mathrm{L}^{-1}$ and immersion time of $10 \mathrm{~min}$; $\mathrm{T} 3$ - peracetic acid at $100 \mathrm{mg} \mathrm{L}^{-1}$ and immersion time of $15 \mathrm{~min}$; $\mathrm{T} 4$ - ozonated water at $1.2 \mathrm{mg} \mathrm{L}^{-1}$ and immersion time of $1 \mathrm{~min}$; T5 - minimally processed lettuce washed by hands with tap water for 1 min was used as a control. Then, the centrifugation was done for removal of water excess from the previous step. A domestic centrifuge (Arno) was used with an average speed of $2200 \mathrm{rpm}$, equivalent to $800 \mathrm{~g}$ (force) for $90 \mathrm{~s}$. The minimally processed lettuce was packaged in low-density polyethylene bags of $60 \mu \mathrm{m}$, containing $200 \mathrm{~g}$. After packaging, three samples from each treatment were taken for analysis on day zero (after processing). The product was stored in a commercial refrigerated display, at $2 \pm 1{ }^{\circ} \mathrm{C}$ and $95 \pm 5 \%$ relative humidity. Three samples from each treatment were taken on $3,6,9$ and 12 days to carry out microbiological analysis.

Two tests were conducted, in July and in October of 2009 , to evaluate the impact of extreme weather conditions of harvesting time on fresh-cut lettuce. In Brazil, these months are part of dry and rainy seasons, respectively. To ensure the safety of minimally processed lettuce, the processing room was previously cleaned according to the good manufacturing practices, as well as all tools and equipments kept inside. The processing room was kept at $15 \pm 3{ }^{\circ} \mathrm{C}$ and all people involved in the processing used personal protective equipment, consisting of apron, $\mathrm{PVC}$ boots, cap, mask and gloves.

\section{Microbiological analysis}

A package containing $200 \mathrm{~g}$ of minimally processed lettuce was considered as a unit sample. To evaluate the mi- 
crobial population reduction, it was considered as initial population the microorganisms count before processing (BP) and as final population the microorganisms count after each treatment (day 0 ) and after the refrigerated storage. All analyses followed the methodologies described in the book of Silva et al. (2007), where $25 \mathrm{~g}$ of sample were aseptically removed from each package and placed in a flask containing $225 \mathrm{~mL}$ of peptone water (2\%), with three replicates per treatment. The samples were submitted to the following microbiological analyses: a) Salmonella spp (by the classical cultural method of presence or absence, ISO 6579); b) total coliforms and Escherichia coli using Tryptose Lauryl Sulfate (LST) Broth (Oxoid LTD., Hampshire, England), Broth Brilliant Green (VB) Broth and $E$. coli (EC) Broth (Oxoid LTD., Hampshire, England) for presumptive test of total coliforms and Levine Eosin Methylene Blue (Oxoid LTD., Hampshire, England) for confirmation of E. coli; the results were expressed in most probable number per gram (MPN g $\left.{ }^{-1}\right)$; c) total count of mesophilic and psychrotrophic using the Plate Count Agar (Oxoid LTD., Hampshire, England) and incubated at $35^{\circ} \mathrm{C}$ $\pm 1{ }^{\circ} \mathrm{C} / 48 \pm 2 \mathrm{~h}$ for mesophilic bacteria and $7{ }^{\circ} \mathrm{C} \pm 1^{\circ} \mathrm{C} /$ 10 days for total count of aerobic psychrotrophic and the results were expressed by colony forming unit per gram (cfu $\left.\mathrm{g}^{-1}\right)$; d) total count of molds and yeasts by plating method for surface measurement using the agar Dichloran Rose Bengal Chloramphenicol (DRBC) and incubated at $22-25{ }^{\circ} \mathrm{C}$ for five days and the results were expressed as $\left(\mathrm{cfu} \mathrm{g}^{-1}\right)$. The experiment was evaluated at random in blocks (July and October 2009) with three replications.

\section{Results and Discussion}

It was not detected presence of Salmonella spp. in the qualitative analysis performed before and immediately after minimal processing, and $E$. coli in samples of minimally processed lettuce during the 12 days of storage. These results were obtained due to the good agricultural practices developed by the producer, mainly with the use of treated water for irrigation, the good manufacturing practices applied on production of minimally processed product and, also, due the efficiency of sanitization performed during processing which ensured that the minimally processed lettuce was within the guidelines established by legislation for coliforms at $45^{\circ} \mathrm{C}$ (Brazil, 2001).

The initial count of total coliforms was $>1.1 \times 10^{3}$ MPN g ${ }^{-1}$ for both July and October 2009 tests. Immediately after minimal processing, lettuce showed a reduction in the count for all treatments, except for T5 (washing in tap water). The greater reduction of $2.5 \mathrm{log}$ cycles was observed in the treatment with chlorine dioxide, which remained unchanged until the sixth day of storage for both tests July and October (Figure 1). The treatment 1 (sodium hypochlorite) and treatment 4 (ozonated water) showed the same reduction of 0.7 log cycles compared to the product before pro- cessing (BP), and kept these values throughout the storage period for the two periods of analysis, except for the sixth day of analysis for October test. These results have fled the expected values and may have been an error in the laboratory.

In spite of the reduction achieved after the chlorine dioxide and peracetic acid treatments, microbial populations increased gradually in these samples after 6 days of storage (Figure 1). Although there are no parameters in the legislation, Berbari et al. (2001) declared that population of total coliforms about $10^{5}(5 \log ) \mathrm{MPN} \mathrm{g}^{-1}$, corresponded to high contamination level of these microorganisms in the product. Data obtained in this experiment did not exceed $10^{3}$ (3 log cycles).

The initial count of mesophilic microorganisms in minimally processed lettuce before processing was 5 and 6 log cycles for July and October tests, respectively. The tap water and ozonated water treatments only reduced 1 log cycle the initial contamination of the product, while the treatment with peracetic acid was able to reduce these microorganisms on fresh-cut lettuce by $4 \log$ cycles in July and 3 $\log$ cycles in October (Figure 2). For these two tests, the chlorine dioxide treatment reduced the initial contamination by $3 \log$ cycles and $1 \log$ cycle, respectively, while the treatment with sodium hypochlorite reduced the initial contamination by $3 \log$ cycles in July and 2 log cycles in October. In addition, the contamination was increased as storage time increased. Zhang et al. (2006) also reported increase in numbers of total bacteria during storage of irradiated fresh-cut lettuce. Although in day 0 , the peracetic acid treatment was better than the sodium hypochlorite treatment in reducing the initial contamination, the sodium hypochlorite showed lower values for the count of mesophilic microorganisms in the last day of storage for the experiment conducted in July compared to other treatments.

For the experiment conducted in October the sample before processing (BP) showed a larger contamination $\left(>6.5 \times 10^{6}\right.$ est) of mesophilic microorganisms compared

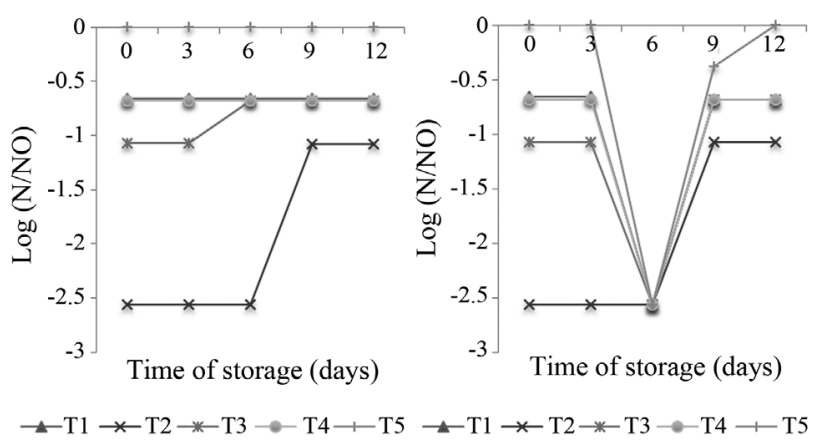

Figure 1 - Count of total coliforms $\left(\mathrm{MPN} \mathrm{g}^{-1}\right)$ in minimally processed lettuce sanitized with different products and stored at $2{ }^{\circ} \mathrm{C} \pm 1{ }^{\circ} \mathrm{C}$ for 12 days in July and October/2009. T1 - Sodium hypochlorite (150 $\left.\mathrm{mg} \mathrm{L}^{-1} / 15 \mathrm{~min}\right)$; $\mathrm{T} 2$ - Chlorine dioxide $\left(60 \mathrm{mg} \mathrm{L}^{-1} / 10 \mathrm{~min}\right)$; $\mathrm{T} 3$ - Peracetic acid (100 mg $\left.\mathrm{L}^{-1} / 15 \mathrm{~min}\right)$; $\mathrm{T} 4$ - Ozonated water $\left(1.2 \mathrm{mg} \mathrm{L}^{-1} / 1 \mathrm{~min}\right)$; T5 - Tap water/1 $\mathrm{min}$. 

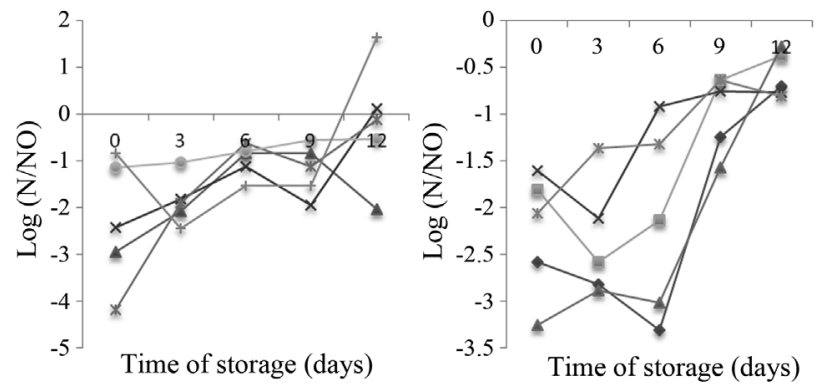

$\rightarrow \mathrm{T} 1 \rightarrow \mathrm{T} 2 \rightarrow \mathrm{T} 3 \rightarrow \mathrm{T} 4 \rightarrow \mathrm{T} 5 \rightarrow \mathrm{T} 1 \rightarrow-\mathrm{T} 2 \rightarrow \mathrm{T} 3 \rightarrow \mathrm{T} 4 \rightarrow \mathrm{T} 5$

Figure 2 - Count of mesophilic aerobic microorganisms $\left(\mathrm{cfu} \mathrm{g}^{-1}\right)$ in minimally processed lettuce sanitized with different products and stored at $2{ }^{\circ} \mathrm{C} \pm 1{ }^{\circ} \mathrm{C}$ for 12 days in July and October/2009. T1 - Sodium hypochlorite $\left(150 \mathrm{mg} \mathrm{L}^{-1} / 15 \mathrm{~min}\right)$; $\mathrm{T} 2$ - Chlorine dioxide $\left(60 \mathrm{mg} \mathrm{L}^{-1}\right.$ / $10 \mathrm{~min}) ; \mathrm{T} 3$ - Peracetic acid (100 $\left.\mathrm{mg} \mathrm{L}^{-1} / 15 \mathrm{~min}\right)$; $\mathrm{T} 4$ - Ozonated water (1.2 $\left.\mathrm{mg} \mathrm{L}^{-1} / 1 \mathrm{~min}\right) ; \mathrm{T} 5$ - Tap water/1 $\mathrm{min}$.

with the July test $\left(1.5 \times 10^{5}\right.$ est $)$ and may be related to temperature, because in July the average temperature was $17^{\circ} \mathrm{C}$, while in October it was close to $22^{\circ} \mathrm{C}$ (CIIAGRO, 2009), which may have influenced the quality of the raw material received from field, since microbial growth is directly related to temperature (Silva et al., 2007). Minimally processed lettuce sanitized with ozonated water and sodium hypochlorite had the same reduction in both period of analysis. According to Ölmez and Akbas (2009) the variety of lettuce, the targeted microorganism, the initial inoculum level, the physiological states of the bacterial cells and the ozone delivery method are the main factors that lead to differences in the effectiveness of ozone treatment.

Comparing the results of this experiment with other studies performed with minimally processed lettuce, it was found that Barriga et al. (1991) also observed increase of 2 to $3 \log$ cycles of mesophilic microorganisms, varied from $10^{4}$ to $10^{7} \mathrm{cfu} \mathrm{g}^{-1}$ for 12 days of storage at $4{ }^{\circ} \mathrm{C}$. When comparing the results with others studies performed with vegetables, it was found by Babic and Watada (1996) initial values of $10^{7}$ to $10^{8} \mathrm{cfu} \mathrm{g}^{-1}$ in the population of mesophilic microorganisms in minimally processed spinach leaves increasing up to $10^{10} \mathrm{cfu} \mathrm{g}^{-1}$ for 9 days of storage. Rinaldi et al. (2009) observed variation of 4 to $7 \mathrm{log}$ cycles to minimally processed cabbage stored in different packages in active and passive atmosphere.

On day zero of the July experiment, the initial contamination of aerobic psychrotrophic was reduced by $1 \log$ cycle for T5, by $2 \log$ cycles for T2 and T4, by $3 \log$ cycles for $\mathrm{T} 1$ and by $5 \log$ cycles for T3, regarding the product before processing (Figure 3). On the sixth day, the treatments $1,2,3$ and 4 showed good results, although the treatment with sodium hypochlorite (T1) had the best one.

For the experiment conducted in October, the T1 reduced the initial contamination by $1 \log$ cycle while the T3 was more efficient and promoted a reduction of $2 \log c y-$ cles. After 3 days of storage there was variation of count of

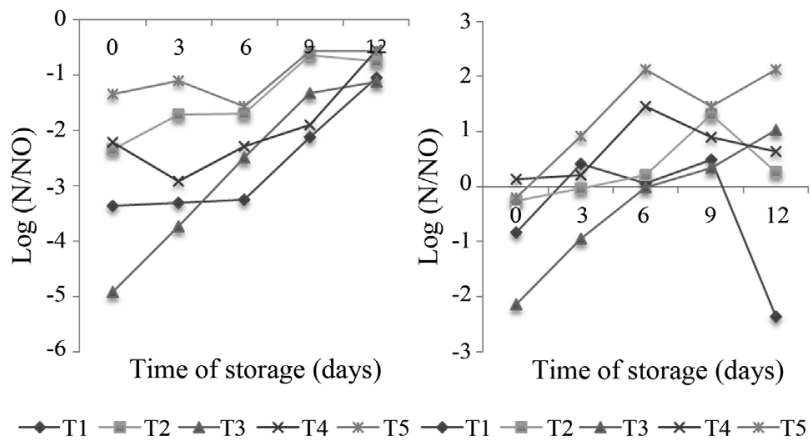

Figure 3 - Count of psychrotrophic aerobic microorganisms (cfu g $\left.{ }^{-1}\right)$ in minimally processed lettuce sanitized with different products and stored at $2{ }^{\circ} \mathrm{C} \pm 1{ }^{\circ} \mathrm{C}$ for 12 days in July and October/2009. T1 - Sodium hypochlorite (150 $\left.\mathrm{mg} \mathrm{L}^{-1} / 15 \mathrm{~min}\right)$; $\mathrm{T} 2$ - Chlorine dioxide $\left(60 \mathrm{mg} \mathrm{L}^{-1} /\right.$ $10 \mathrm{~min})$; T3 - Peracetic acid (100 $\left.\mathrm{mg} \mathrm{L}^{-1} / 15 \mathrm{~min}\right)$; T4 - Ozonated water (1.2 $\left.\mathrm{mg} \mathrm{L}^{-1} / 1 \mathrm{~min}\right)$; $\mathrm{T} 5$ - Tap water/1 min.

psychrotrophic aerobic microorganisms for all samples analyzed.

For yeasts and molds, they were not found references that cite the limiting count the shelf-life of minimally processed products, however, in accordance with $\mathrm{RDC} 12$ (Brazil, 2001), the tolerated limit for food safety is $10^{3} \mathrm{cfu} \mathrm{g}^{-1}$. Berbari et al. (2001) affirm that population of fungi about $10^{4}(4 \mathrm{log}) \mathrm{cfu} \mathrm{g}^{-1}$ correspond to high contamination of these microorganisms in the product. These authors also claimed that the operation of washing with tap water reduces by 1 log cycle the fungi count. In Figure 4, it was observed, for the July test, the reduction of fungi contamination by 1 log cycle of the product before processing in the washed with tap water (T5) and ozonated water (T4). The other treatments (T1, T2 and T3) showed an initial reduction of $2 \log$ cycles. For October test, this relationship was not observed for tap water treatment.

It was verified, in the July test, that initially all the treatments showed some reduction in the population of yeasts and molds. After 3 days of storage, count of these microorganisms reached values not tolerated by RDC12

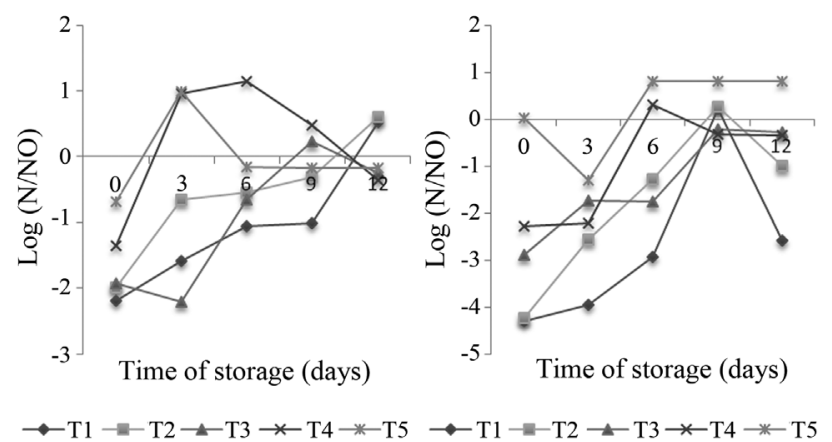

Figure 4 - Count of yeasts and molds $\left(\mathrm{cfu} \mathrm{g}^{-1}\right)$ in minimally processed lettuce sanitized with different products and stored at $2{ }^{\circ} \mathrm{C} \pm 1{ }^{\circ} \mathrm{C}$ for 12 days in July and October/2009. T1 - Sodium hypochlorite ( $\left.150 \mathrm{mg} \mathrm{L}^{-1} / 15 \mathrm{~min}\right)$; $\mathrm{T} 2$ - Chlorine dioxide $\left(60 \mathrm{mg} \mathrm{L} \mathrm{m}^{-1} / 10 \mathrm{~min}\right)$; T3 - Peracetic acid (100 $\left.\mathrm{mg} \mathrm{L}^{-1} / 15 \mathrm{~min}\right)$; $\mathrm{T} 4$ - Ozonated water $\left(1.2 \mathrm{mg} \mathrm{L}^{-1} / 1 \mathrm{~min}\right)$; T5 - Tap water/1 $\mathrm{min}$. 
(Brazil, 2001) for samples treated with ozonated water and tap water. These results are higher than those found by Sigrist (2002) that not observed counts exceeding $10^{2} \mathrm{cfu}^{-1}$ during storage of minimally processed cauliflower and rocket. The results of this experiment for the peracetic acid also differ from those obtained by Srebernich (2007) with minimally processed green seasoning.

The sensitivity of different bacteria to certain sanitizers is variable and to guarantee a food secure for consumption, the objectives of vegetables sanitization is the reduction or elimination of these microorganisms; the sanitizing product should be dictated by the pathogen and / or deteriorating more problematic and circumstances and needs of the moment.

The results of these experiments demonstrated that minimally processed lettuce had absence in all samples of E. coli and Salmonella spp. The treatments of chlorine dioxide, peracetic acid and ozonated water promoted reduction in microbial population counts in the processed product and can be used as substitutes for sodium hypochlorite although their efficacy varied depending of the type of washing solution and group of microorganisms. Based on that population levels greater than $10^{5} \mathrm{cfu} \mathrm{g}^{-1}$ are already indicators of the end of products shelf-life, it can be conclude that under refrigeration $\left(2{ }^{\circ} \mathrm{C}\right)$ the durability of minimally processed lettuce was six days for all treatments. These alternative compounds have given a shelf-life of six days for minimally processed lettuce and 12 days for sodium hypochlorite.

\section{References}

Babic I, Watada AE (1996) Microbial populations of fresh-cut spinach leaves affected by controlled atmospheres. Postharvest Biol Technol 9:187-193.

Berbari SAG, Paschoalino JE, Silveira NFA (2001) Efeito do cloro na água de lavagem para desinfecção de alface minimamente processada. Ciênc Tecnol Aliment 21:197-201.

Barriga MI, Trachy G, Willemont C, Simard RE (1991) Microbial changes in shredded iceberg lettuce stored under controlled atmospheres. J Food Sci 56:1586-1588.

Brazil, Ministério da Saúde. Agência Nacional de Vigilância Sanitária (2001) Resolução RDC n ${ }^{\circ} 12$, de 02 de janeiro de 2001. Aprova o Regulamento Técnico sobre padrões microbiológicos para alimentos. Diário Oficial da União; Poder Executivo, de 10 de janeiro de 2001.

Bari ML, Nazuka E, Sabina Y, Todoriki S, Isshiki K (2003) Chemical and irradiation treatments for killing Escherichia coli $\mathrm{O} 157: \mathrm{H} 7$ on alfafa, radish, and mung bean seed. J Food Prot 66:767-774.

Baur S, Klaiber R, Hammes WP, Carle R (2004) Sensory and microbiological quality of shredded, packaged iceberg lettuce as affected by pre-washing procedures with chlorinated and ozonated water. Innov Food Sci Emerg Technol 5:45-55.

Chitarra MIF, Chitarra AB (2007) Processamento mínimo de alface. In: Moretti CL (ed) Manual de Processamento Mínimo de Frutas e Hortaliças. Brasília: EMBRAPA Hortaliças e SEBRAE, cap.16:301-341.
CIIAGRO (2009) Centro Integrado de informações agrometeorológicas do Estado de São Paulo. www.ciiagro.sp.gov.br. Acesso em: 20 de dezembro de 2009.

Costa JB (2007) Avaliação ecotoxicológica de efluente de tratamento secundário de esgoto sanitário após desinfecção com ácido peracético, cloro, ozônio e radiação ultravioleta. São Carlos, Brazil, 180 p. (Tese de Doutorado. Escola de Engenharia de São Carlos. Universidade de São Paulo).

Darezzo HM (2004) Determinação de composição gasosa e sistemas de embalagens adequadas para conservação de alface americana 'Lorca' minimamente processada. Campinas, Brazil, 155p. (Tese Doutorado. Faculdade de Engenharia Agrícola. Universidade Estadual de Campinas).

U.S. Food and Drug Administration (2002) Secondary direct food additives permitted in food for human consumption. Code of federal regulations. Title 21 - Foods and Drugs. v. 3. Part 173. Section 173.315.2000.

Frank C, Werber D, Cramer JP (2011) Epidemic Profile of ShigaToxin-Producing Escherichia coli O104:H4 Outbreak in Germany. New Engl J Med 365:1771-1780.

Hua G, Reckhow DA (2007) Comparison of disinfection byproduct formation from chlorine and alternative disinfectants. Water Res 41:1667-1678.

Kim JG, Yousef AE, Dave S (1999) Application of ozone for enhancing the microbiological safety and quality of foods: a review. J Food Prot 62:1071-1087.

Klaiber RG, Baur S, Wolf G, Hammes WP, Carle R (2005) Quality of minimally processed carrots as affected by warm water washing and chlorination. Innov Food Sci Emerg Technol 6:351-362.

López-Gálvez F, Allende A, Truchado P, Martínez-Sánchez A, Tudela JA, Selma MV, Gil MI (2010) Suitability of aqueous chlorine dioxide $v s$. sodium hypochlorite as an effective sanitizer for preserving quality of fresh-cut lettuce while avoiding by-product formation. Postharvest Biol Technol 55:53-60.

Ölmez H, Akbas MY (2009) Optimization of ozone treatment of fresh-cut green leaf lettuce. J Food Eng 90:487-494.

Ölmez H, Kretzschamr U (2009) Potential alternative disinfection methods for organic fresh-cut industry for minimizing water consumption and environmental impact. LWT- Food Sci Technol 42:686-693.

Prestes EB (2007) Avaliação da eficiência do ozônio como sanitizante em hortaliças folhosas minimamente processadas. 135 p. (Tese Doutorado. Faculdade de Engenharia de Alimentos, Universidade Estadual de Campinas).

Richardson SD, Thruston Jr AD, Caughran TV, Chen PH, Collette TW, Schenck KM, Lykins Jr BW, Rav-Acha C, Glezer V (2000) Identification of new drinking water disinfection by-products from ozone, chlorine dioxide, chloramine, and chlorine. Water Air Soil Pollution 123:95-102.

Rico D, Martin-Diana AB, Barat JM, Barry-Ryan C (2007) Extending and measuring the quality of fresh-cut fruit and vegetables: a review. Trends Food Sci Tech 18:373-386.

Rinaldi MM, Benedetti BC, Sarantópoulos CIGL, Moretti CL (2009) Estabilidade de repolho minimamente processado sob diferentes sistemas de embalagem. Ciênc Tecnol Aliment 29:310-315.

Sigrist JMM (2002) Estudos fisiológicos e tecnológicos de couve-flor e rúcula minimamente processadas. Piracicaba, 
Brazil, 112 p. (Tese Doutorado. Escola Superior de Agricultura Luiz de Queiroz, Universidade de São Paulo).

Silva N, Junqueira VCA, Silveira, NFA, Taniwaki MH, Santos RFS, Gomes RAR (2007) Manual de métodos de análise microbiológica de alimentos. 3 ed. Varela, São Paulo, $552 \mathrm{pp}$.

Srebernich SM (2007) Using chlorine dioxide and peracetic acid as substitutes for sodium hypochlorite in the sanitization of minimally processed green seasoning. Ciênc Tecnol Aliment 27:744-750.
Tancredi RCP, Moraes OM, Marin VA (2005) Vigilância sanitária do município do Rio de Janeiro: Considerações sobre as ações fiscais na área de alimentos. Hig Aliment 19:21-26.

Zhang L, Zhaoxin L, Lu F, Bie X (2006) Effect of $\gamma$ irradiation on quality-maintaing of fresh-cut lettuce. Food Control $17: 225-228$

All the content of the journal, except where otherwise noted, is licensed under a Creative Commons License CC BY-NC. 